\title{
PEMANFAATAN MIDDLEWARE LAYER UNTUK MULTI PLATFORM PADA MOBILE DAN DESKTOP
}

\author{
Hendro Purwoko \\ Informatika, Universitas Indraprasta PGRI \\ hendroprwk08@gmail.com
}

Submitted August 4, 2019; Revised October 10, 2019; Accepted October 25, 2019

\begin{abstract}
Abstrak
Teknologi saat ini memiliki banyak platform dari segi perangkat keras dan lunak, seperti yang kita ketahui beberapa perangkat pun memiliki bahasa pemprograman yang berbeda pula. Hal ini rumit jika didapati sistem yang ada, masih menggunakan metode Client-Server yang hanya berdiri pada satu platform saja sehingga perlu mengusulkan arsitektur untuk pengembangan aplikasi mobile dengan menggunakan infrastruktur yang ada, Dampak dari itu muncullah kombinasi logika pemrograman dengan basis data terdistribusi yang disebut middleware, yang cara berkomunikasinya disepakati agar memiliki kesatuan. Kondisi multi platform juga memerlukan internet agar terhubung dengan pemakai aplikasi karena menggunakan protokol HTTP atau HTTPS sehingga pertukaran data dapat berjalan dengan baik. Hasil dari proses basis data menggunakan format JSON yang dinilai efektif dan telah terbukti kehandalannya dalam menghasilkan keluaran yang dapat diuraikan oleh multi platform. Pemanfaatan middleware menggunakan metode Rapid Application Development agar proses pembangunan perangkat lunak efektif karena penanganan kesalahan yang cepat sehingga mampu membangun perangkat lunak yang dapat melayani berbagai platform dan mudah untuk dikembangkan dimasa mendatang.
\end{abstract}

Kata Kunci: Multi Platfrom, Android, Desktop, API, RESTful API, JSON, Middleware, Rapid Application Development

\begin{abstract}
Technology currently has many platforms from hardware and software, as we know some devices also have different programming languages. This is complicated if the existing system still uses the ClientServer method that only stands on one platform, so it is necessary to propose architecture for mobile application development using the existing infrastructure, so it appears A combination of programming logic with a distributed database called Middleware, which communicates to have unity. Multi-platform conditions also require the Internet to connect with application users because it uses HTTP or HTTPS protocols so that data exchange can run. The result of database process is formed in JSON format which is reliable and effective and has been proven reliability in generating output that can be read by multi platform. Development of Middleware using Rapid Application Development method to make software development process effective and fast error handling so as to build software that can serve various platforms and easy to develop.
\end{abstract}

Key Words: Multi Platfrom, Android, Desktop, API, RESTful API, JSON, Middleware, Rapid Application Development

\section{PENDAHULUAN}

Guna mendukung kemajuan teknologi yang terus berkembang, berbagai institusi dan perusahaan mengembangkan sistem komputer yang dapat digunakan untuk berbagai kalangan agar memudahkan serta memanjakan stakeholders, hal ini rumit jika didapati sistem yang ada, masih menggunakan metode Client-Server yang hanya berdiri pada satu platform saja sehingga perlu mengusulkan arsitektur untuk pengembangan aplikasi mobile dengan menggunakan infrastruktur institusi yang ada [8]. 
Keadaan saat ini berbagai perangkat keras dan lunak baru muncul untuk memenuhi kebutuhan berbagai elemen industri, namun terkadang tak berbanding lurus dengan keadaan hingga para pembuat perangkat lunak atau programmer pun harus bekerja dengan berbagai Sistem Operasi, platform dan bahasa pemrograman berbeda menjadi aplikasi yang dapat terhubung dengan aplikasi lain melalui jaringan global [3].

Salah satu solusi agar berbagai platform tersebut menjadi satu kesatuan adalah dengan memanfaatkan Web Service API yang dikombinasikan menggunakan REST atau disebut pula dengan RESTful API [1] kemudian menggunakan HTTP atau HTTPS sebagai protokol dan menghasilkan keluaran berupa notasi JSON agar mudah diurai serta merupakan bahasa pertukaran data yang ideal [5] agar dapat digunakan oleh berbagai platform.

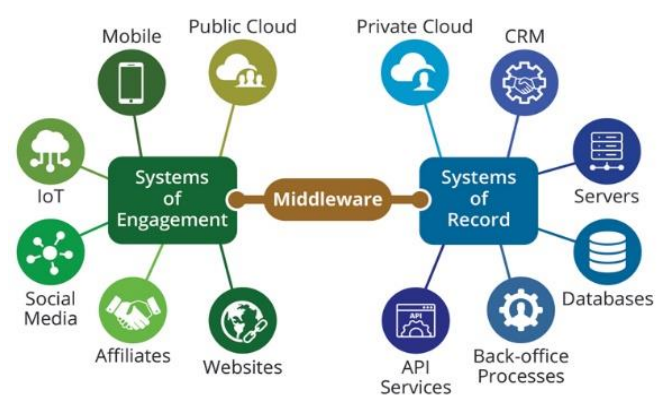

Gambar 1. Konsep Middleware (Corebitts, 2019)

Kombinasi tersebut merupakan alur hubungan antara logika pemrograman dengan basis data terdistribusi yang disebut middleware. Menurut Oracle, middleware adalah lapisan perangkat lunak yang terletak di antara sistem operasi dan aplikasi di setiap sisi jaringan komputer terdistribusi [7], sedangkan menurut technopedia middleware mirip dengan sistem operasi karena dapat mendukung program aplikasi lain, menyediakan interaksi terkontrol, mencegah gangguan antara komputasi dan memfasilitasi interaksi antara komputasi pada komputer yang berbeda melalui jaringan Layanan Komunikasi [9].

Dalam bahasan ini akan membangun perangkat lunak menggunakan RESTful API yang dapat mengakses basis data dan diolah menjadi keluaran berupa JSON sebagai lapisan middleware yang akan berinteraksi dan dapat dimanfaatkan oleh bahasa pemprograman $\mathrm{C} \#$ berbasis Desktop dengan Sistem Operasi Windows dan Sistem Operasi Android dengan bahasa pemprograman Java sehingga kedua platform tersebut menjadi satu kesatuan yang utuh dalam mengolah data.

\section{METODE PENELITIAN}

Metode RAD (Rapid Application Development) merupakan metode pengembangan dari Waterfall atau metode tradisional pada SDLC yang digunakan untuk membangun simulasi middleware.
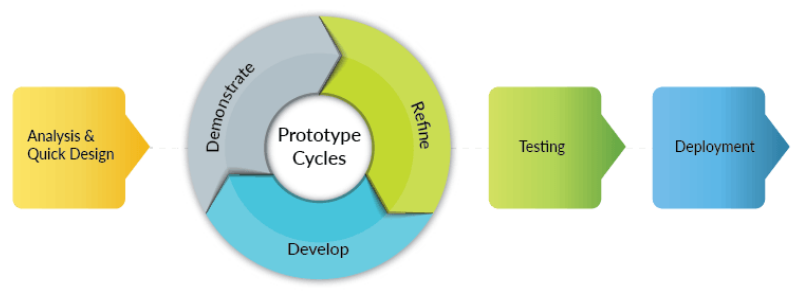

Perbedaan RAD dengan Waterfall berada pada tahap pembangunan perangkat lunak yang dilakukan secara terus menerus dan responsif, jika terjadi kesalahan maka langsung dilakukan perbaikan sehingga saat ingin memasuki tahap pengujian minim terjadi kesalahan. Adapun penerapan dari metode tersebut dijelaskan pada tabel dibawah ini: 
Tabel 1.Alur Proses Pembangunan Perangkat Lunak

\begin{tabular}{|c|c|c|c|}
\hline No. & Aktifitas & Hasil & Keterangan \\
\hline 1 & $\begin{array}{l}\text { Menganalisa } \\
\text { kebutuhan } \\
\text { sistem. }\end{array}$ & $\begin{array}{l}\text { struktur basis } \\
\text { data, bahasa } \\
\text { pemprogram } \\
\text { an yang } \\
\text { dibutuhkan }\end{array}$ & $\begin{array}{l}\text { Bahasa } \\
\text { pemrograman } \\
\text { yang digunakan } \\
\text { adalah Java } \\
\text { dan C\# }\end{array}$ \\
\hline 2 & $\begin{array}{l}\text { Kebutuhan } \\
\text { integrasi } \\
\text { dengan } \\
\text { melakukan } \\
\text { perbandingan } \\
\text { host yang akan } \\
\text { digunakan }\end{array}$ & $\begin{array}{l}\text { Menggunaka } \\
\mathrm{n} \text { host } \\
\text { dengan } \\
\text { domain }\end{array}$ & $\begin{array}{l}\text { Bahasa } \\
\text { pemprograman } \\
\text { pada server } \\
\text { menggunakan } \\
\text { PHP dengan } \\
\text { basis data } \\
\text { MySQL }\end{array}$ \\
\hline 3 & $\begin{array}{l}\text { Perancangan } \\
\text { basis data }\end{array}$ & $\begin{array}{l}\text { Pembentuka } \\
\mathrm{n} \text { tabel, view } \\
\text { dan prosedur } \\
\text { operasi: } \\
\text { menambah, } \\
\text { menghapus } \\
\text { dan } \\
\text { mengubah } \\
\text { data }\end{array}$ & \\
\hline 4 & $\begin{array}{l}\text { Perancangan } \\
\text { antar-muka }\end{array}$ & $\begin{array}{l}\text { Pada kedua } \\
\text { platform : } \\
\text { Desktop dan } \\
\text { Mobile }\end{array}$ & \\
\hline 5 & $\begin{array}{l}\text { Pengkodean } \\
\text { Desktop }\end{array}$ & $\begin{array}{l}\text { Menggunaka } \\
\mathrm{n} \text { Microsoft } \\
\text { Visual studio } \\
\text { dan bahasa } \\
\text { pemprogram } \\
\text { an C\# }\end{array}$ & $\begin{array}{l}\text { Jika masih } \\
\text { terdapat bugs } \\
\text { maka perlu } \\
\text { dilakukan } \\
\text { perbaikan }\end{array}$ \\
\hline 6 & $\begin{array}{l}\text { Pengkodean } \\
\text { Android }\end{array}$ & $\begin{array}{l}\text { Dengan } \\
\text { bahasa } \\
\text { pemprogram } \\
\text { an Java }\end{array}$ & $\begin{array}{l}\text { Jika masih } \\
\text { terdapat bugs } \\
\text { maka perlu } \\
\text { dilakukan } \\
\text { perbaikan }\end{array}$ \\
\hline 7 & $\begin{array}{l}\text { Pengujian } \\
\text { seluruh } \\
\text { perangkat lunak }\end{array}$ & $\begin{array}{l}\text { Android, } \\
\text { Desktop dan } \\
\text { Web }\end{array}$ & $\begin{array}{l}\text { Bila terjadi } \\
\text { kesalahan } \\
\text { maka perlu } \\
\text { melakukan } \\
\text { revisi pada } \\
\text { bagian yang } \\
\text { mengalami } \\
\text { bugs saja }\end{array}$ \\
\hline
\end{tabular}

\section{HASIL DAN PEMBAHASAN}

Tahap awal dalam membangun simulasi middleware adalah dengan mempersiapkan host dan basis data, mengingat bahwa platform akan menggunakan protokol HTTP, maka salah satu cara adalah menggunakan PHP secara native untuk berkomunikasi dengan basis data pada lapisan middleware, merespon request dari client dan sebagai penyedia keluaran berformat JSON, sebagai salah satu pendukung keamanan, protokol yang digunakan adalah HTTPS yang mengenkripsi setiap request yang dikirim dari client. Bentuk penerapan request akan dikirimkan melalui alamat URL yang selanjutnya akan di proses server. Berikut cara pengiriman perintah yang akan diproses server:

\section{Memasukkan data}

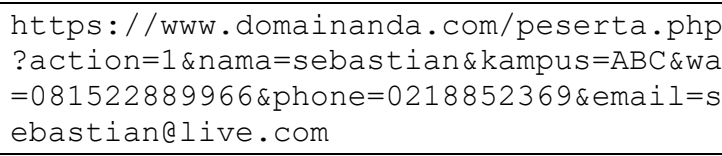

\section{Memperbarui data}

https: / / www. domainanda. com/peserta.php
?action=2\&id=2 \&nama=sebastian \&kampus=U
nindra \&wa=0 $81522889977 \&$ phone=021885236
$9 \&$ email=sebastian@gmail. com

Menampilkan seluruh data

https://www.domainanda.com/peserta.php ?action=4

Menghapus data

https://www. domainanda.com/peserta.php ?action $=3 \& i d=2$

Pencarian data

https://www. domainanda.com/peserta.php ?action=5\&find=andre

Berdasarkan kode tersebut seluruh platform cukup mengikuti URL yang telah diberikan dan tak perlu melakukan pengaturan basis data, selanjutnya pemrogram perangkat lunak cukup melakukan permintaan dan penerimaan data saja. Adapun kode PHP yang digunakan sebagai peladen client terbagi menjadi dua kode, yang pertama kode berupa Class yang mengoperasikan basis data seperti yang diuraikan dibawah.

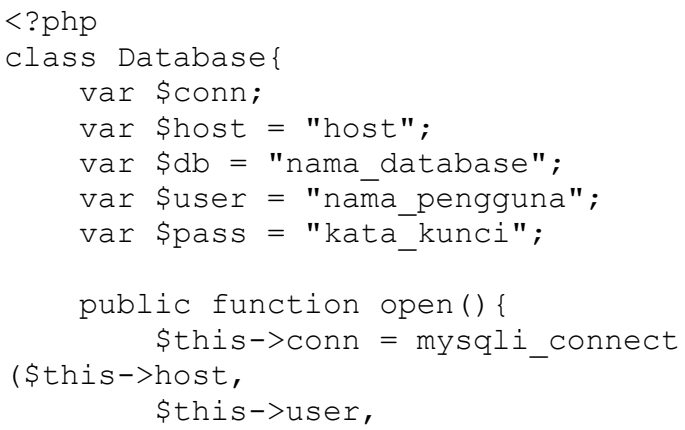




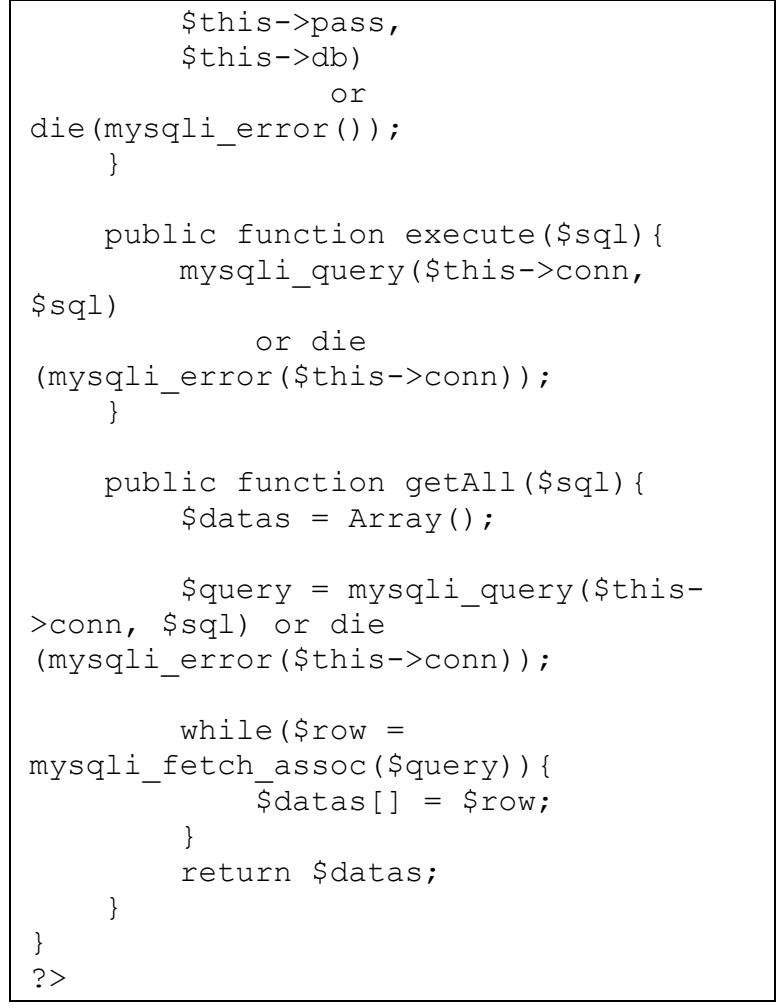

\section{Kemudian yang kedua adalah kode yang} berkerja sebagai peladen client.

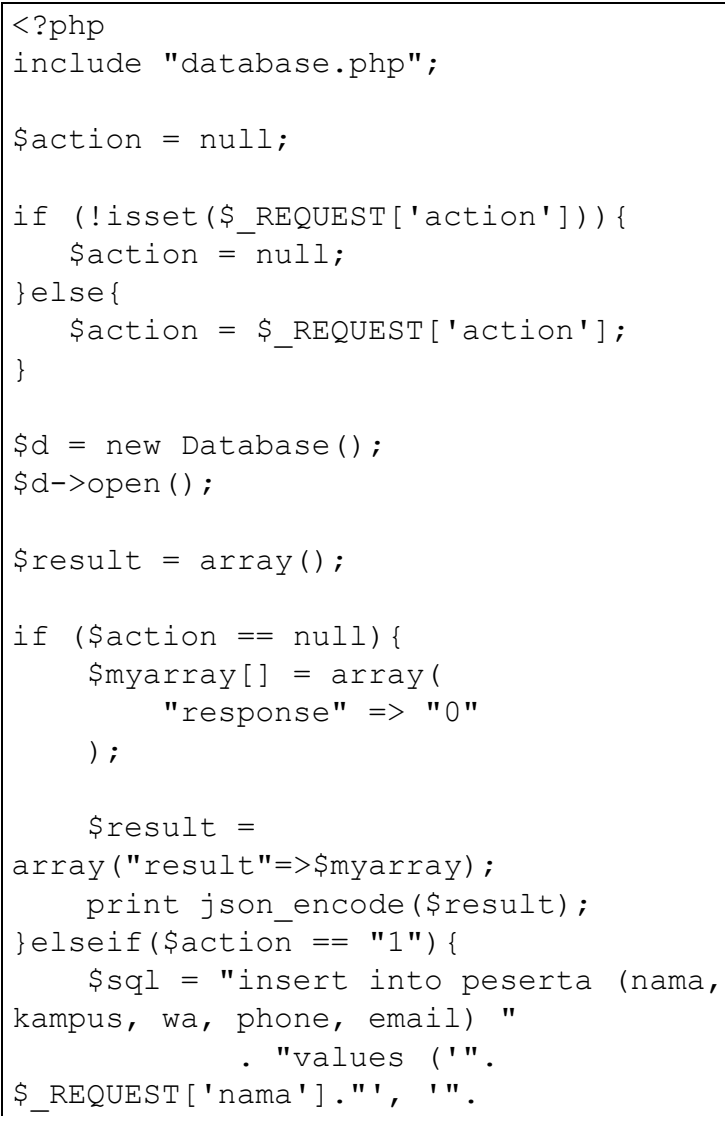

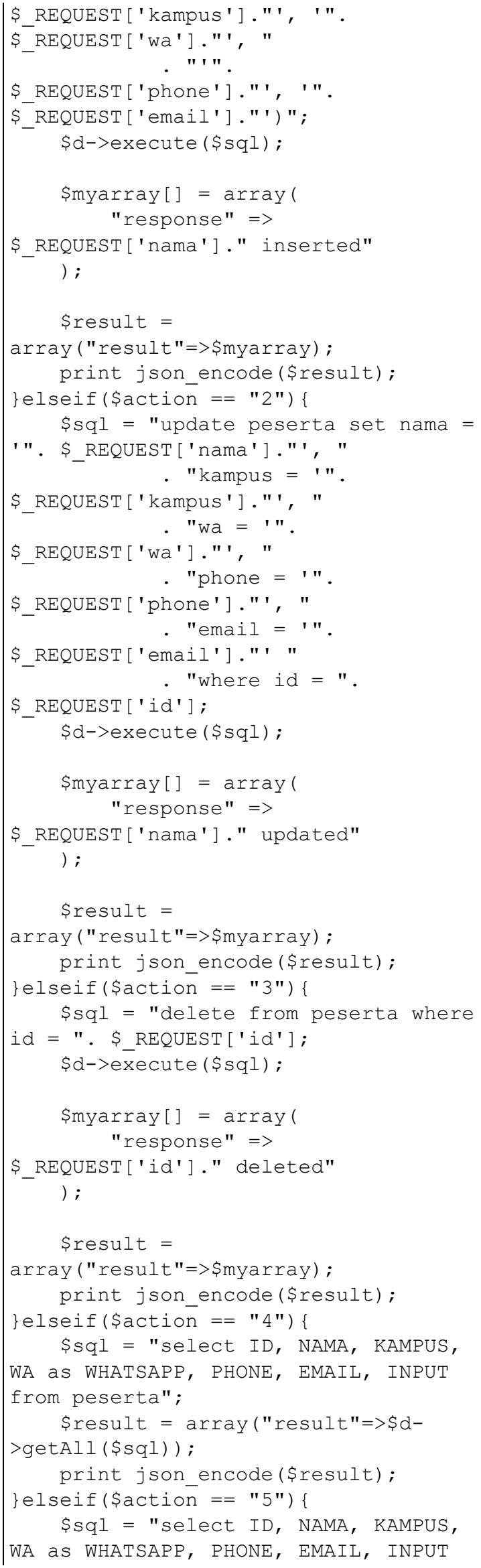




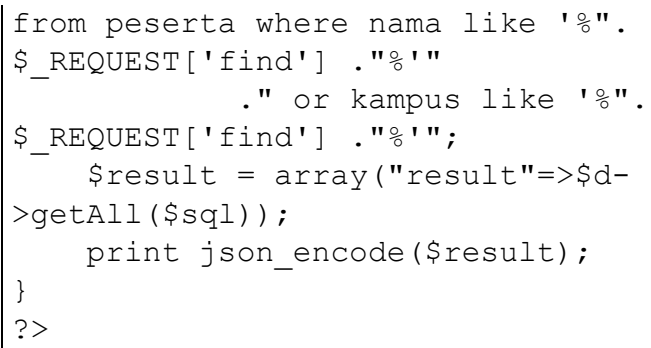

\section{Pembangunan Perangkat Lunak Berbasis Desktop}

Menggunakan Microsoft Visual Studio, dengan bahasa pemrograman $\mathrm{C \#}$. Walaupun Microsoft Visual Studio mampu membangun berbagai basis platform, namun kali ini digunakan hanya untuk desktop saja. Adapun bentuk antar-muka Microfost Visual Studio seperti tergambar dibawah.

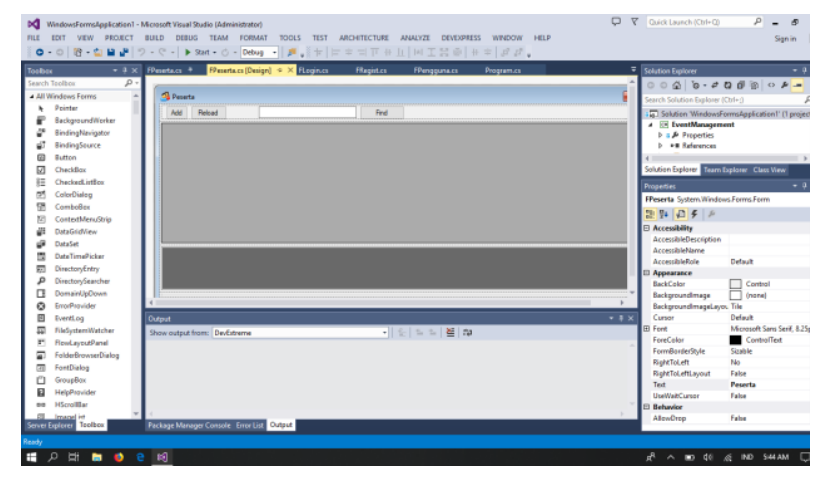

Gambar 2.Aantar Muka Microsoft Visual Studio

Untuk menjalankan URL yang telah ditentukan pada bahasan diatas, maka proses akan dijalankan dalam beberapa kondisi:

1. Memuat Form dengan memanggil URL yang berfungsi menampilkan data pada Data grid:

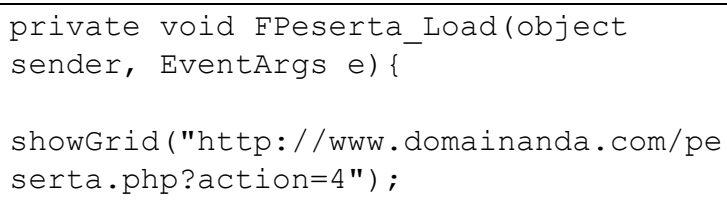

2. Menyimpan dan memperbarui data

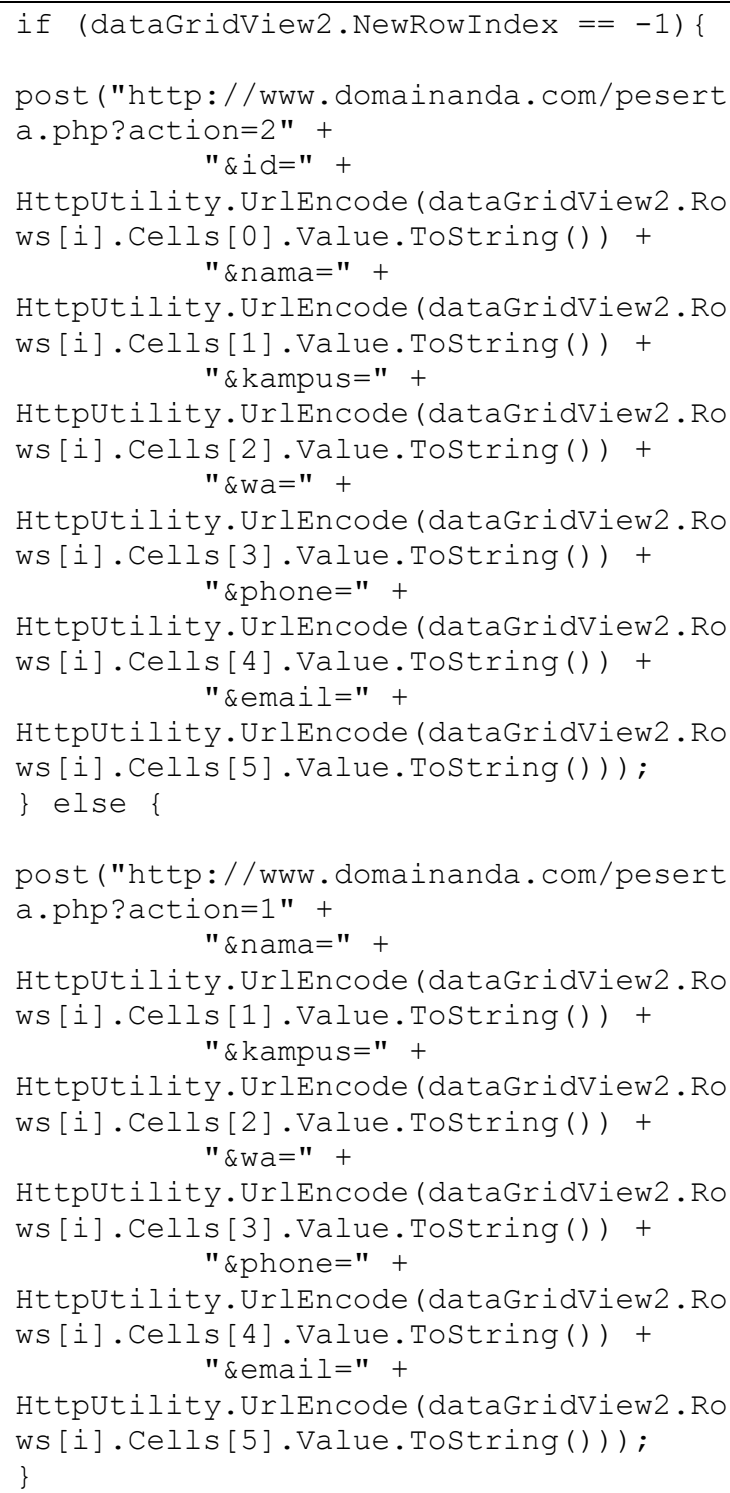

3. Menghapus data

post ("http://www.domainanda.com/pesert a.php?action $=3 \& i d="+$

dataGridView2.Rows [i].Cells[0].Value.T ostring());

4. Mencari data

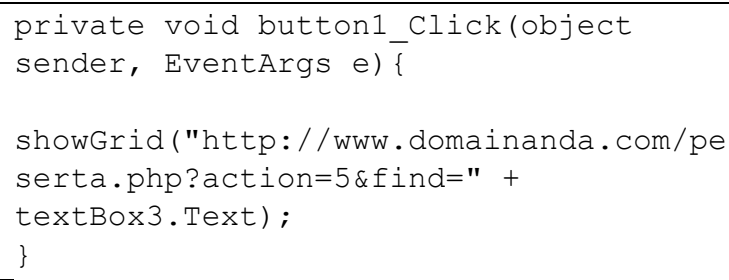

Bentuk antar muka dalam menerapkan pola URL diatas digambarkan seperti 
dibawah ini. Proses tambah data, simpan, hapus dan pencarian menjadi lebih sederhana dikarenakan tak adanya pengaturan basis data.

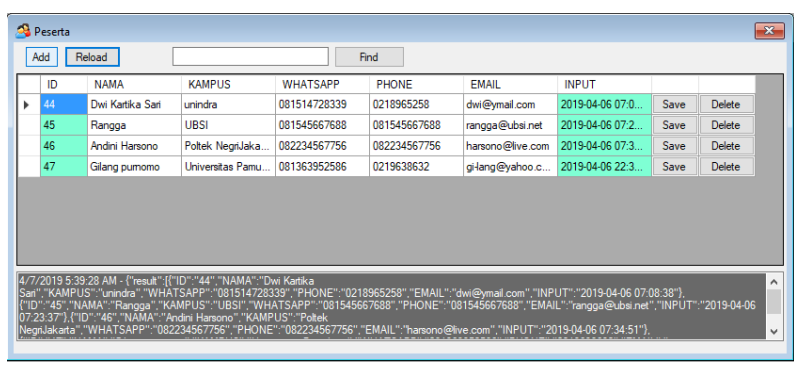

Gambar 3. Antar Muka Berbasis Desktop

\section{Pembangunan Perangkat Lunak Berbasis Android}

Dibangun menggunakan perangkat lunak Android Studio yang mendukung bahasa pemrograman Kotlin, Java dan Dart. Namun pada bahasan ini menggunakan Java dengan XML sebagai layout.

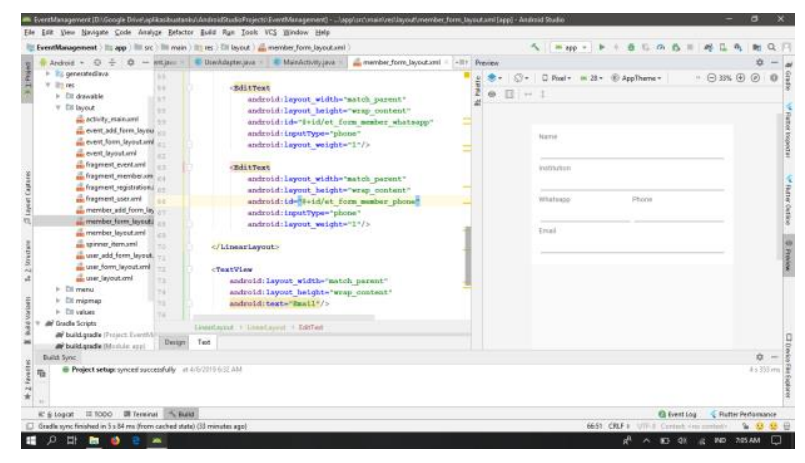

Gambar 4. Antar Muka Android Studio

Teknis pemanfaatan HTTP pada bahasan ini menggunakan library Volley untuk mengirim URL dan mengurai JSON sebagai hasil keluaran. Teknis pengoperasian URL tersebut akan diuraikan dibawah ini:

1. Memuat Form dengan memanggil URL yang berfungsi menampilkan data:

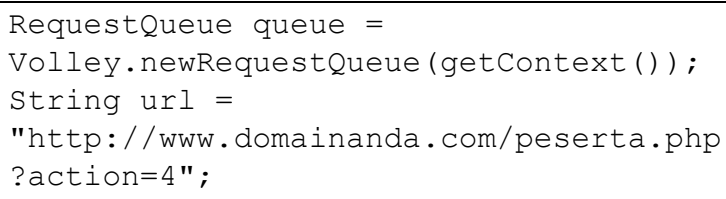

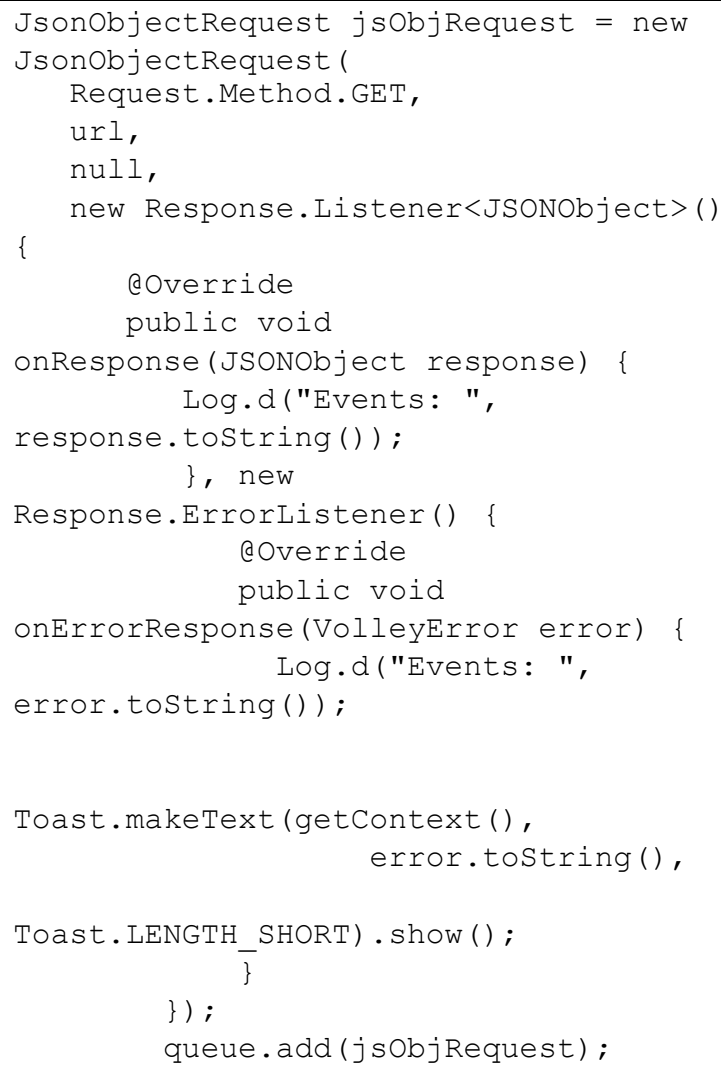

2. Menyimpan data

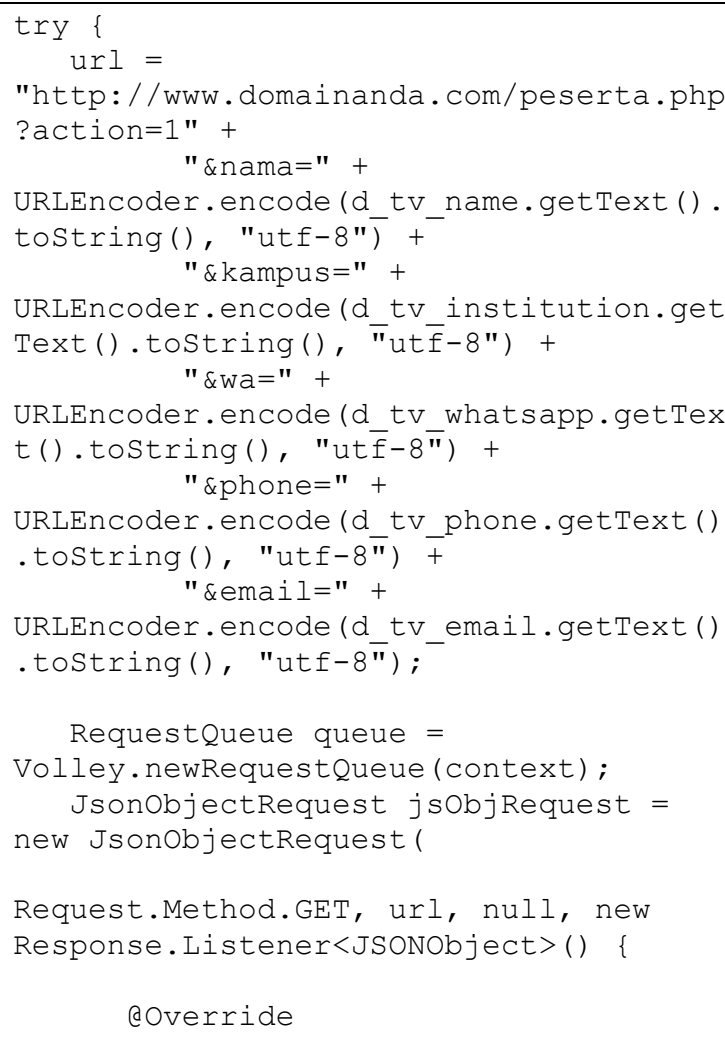




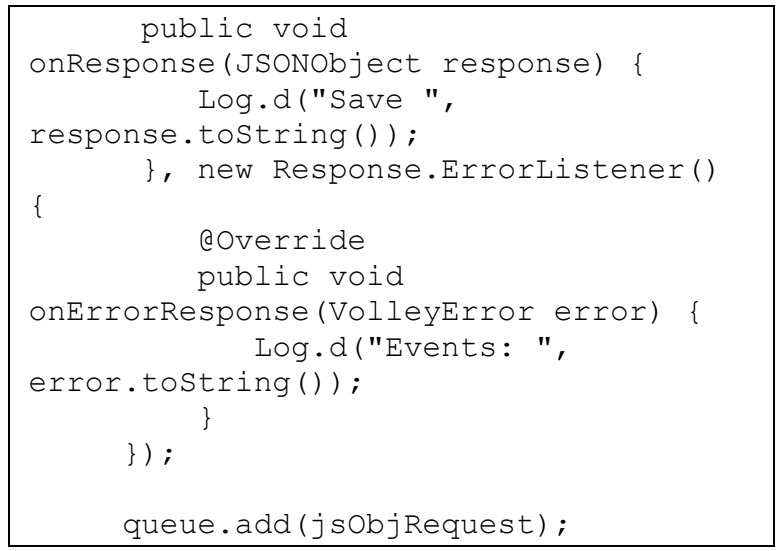

\section{Memperbarui data}

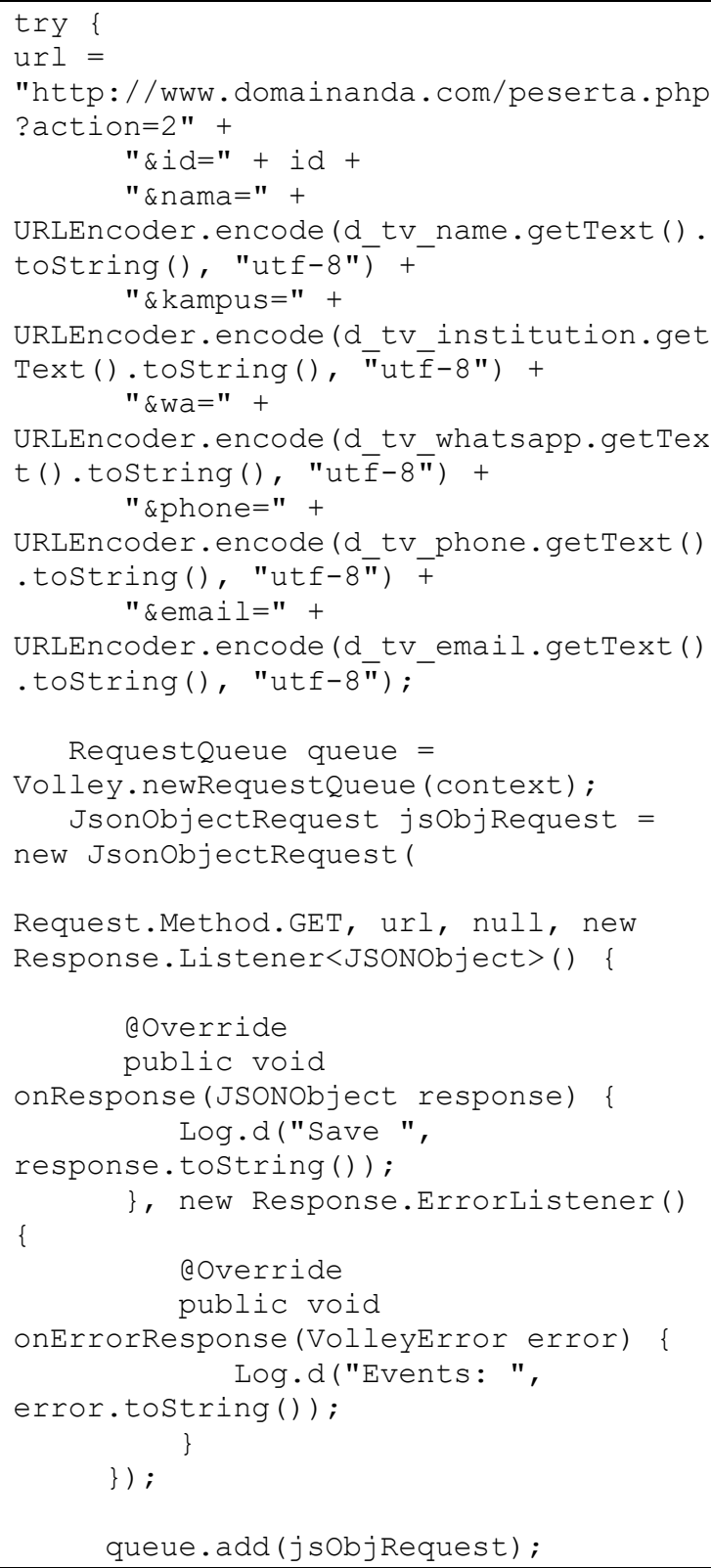

\section{Menghapus data}

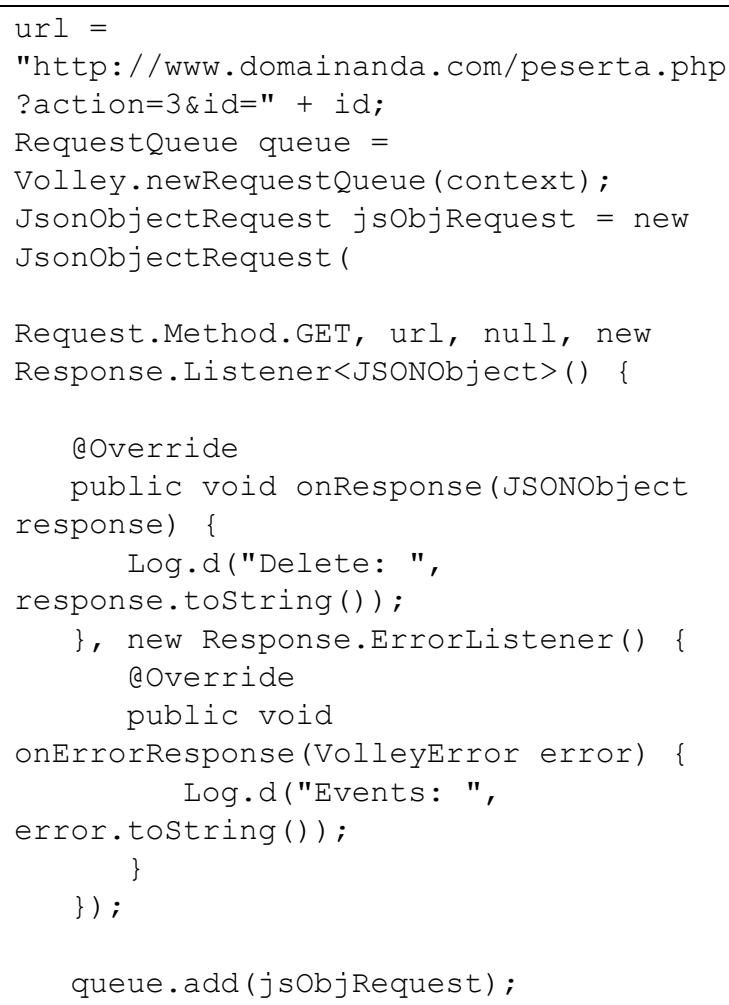

\section{Mencari data}

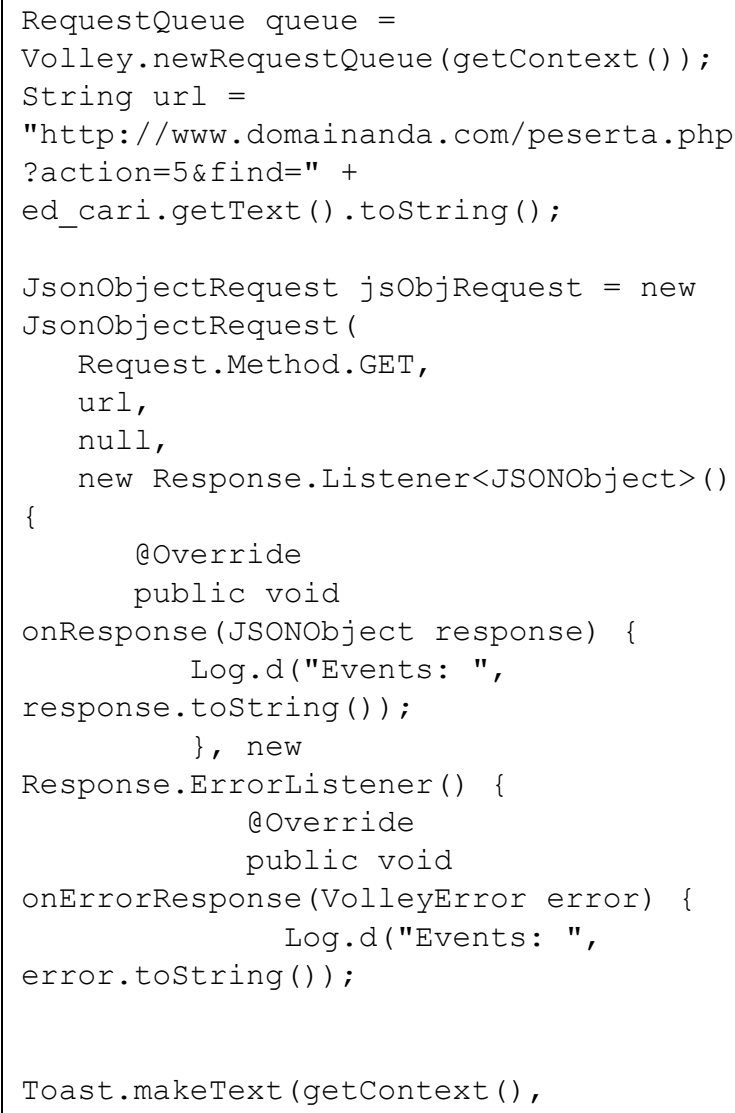

Toast.makeText (getContext (), 


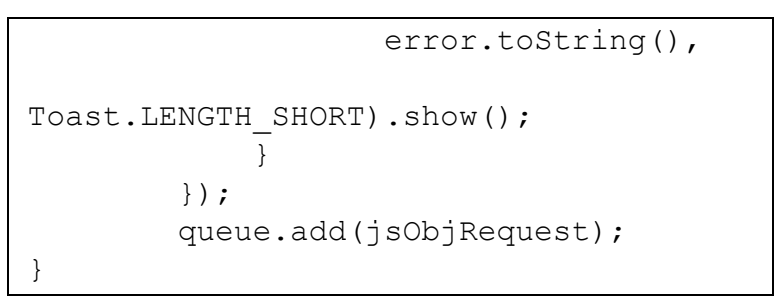

Dari rangkuman kode diatas terbentuklah antar muka seperti tergambar dibawah. Tanda tambah disisi atas berguna untuk menambahkan data, sedangkan untuk mengubah dan menghapus data cukup tekan data yang ingin diubah.

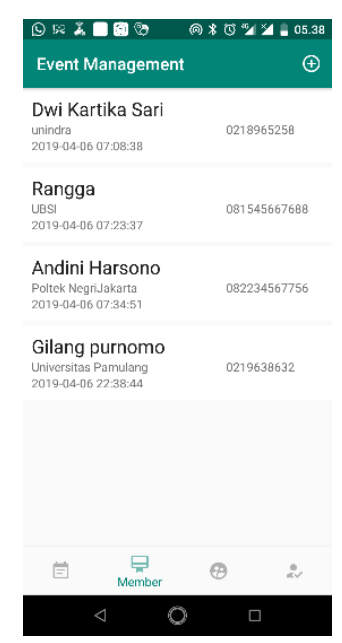

Gambar 5. Antar Muka pada Platform Android

\section{SIMPULAN}

Lapisan middleware yang berisi logika pemprograman dan operasi basis data mampu melayani kebutuhan platform Desktop berbahasa pemrograman C\# dan platform bersistem operasi Android berbahasa pemprograman Java. Keduanya memiliki respon terhadap data secara langsung atau real time dengan perbedaan cara saat mengurai hasil keluaran berupa JSON.

Guna menambah kehandalan pada sisi middleware perlu melakukan perubahan kode PHP Native dengan menggunakan Framework Laravel atau NodeJS yang memiliki performa cepat dan keamanan yang baik.

\section{DAFTAR PUSTAKA}

[1] Amin Rulloh, D. E. (2017). Implementasi REST API pada Aplikasi Panduan Kepaskibraan. Teknikom, 8589.

[2] Corebitts. (2019). Middleware Services. Diambil kembali dari Corebitts:

https://www.corebitts.com/middleware -services/

[3] Deitel, P. D. (2014). Android How To Program. New Jersey: Prentice Hall.

[4] Dody Agung S, H. D. (2015). Penerapan RESTful Web Service dan JSON pada Application Programming Interface (API) Sistem Informasi Perkembangan Ayam Broiler Berbasis Kemitraan. Salatiga: Universitas Kristen Satya Wacana.

[5] Json. (2019). Pengenalan JSON. Diambil kembali dari Json.org: https://www.json.org/

[6] Magableh, B. (2019). Context Oriented Software Middleware. arXiv.

[7] Oracle. (2019). Overview of Oracle Fusion Middleware. Diambil kembali dari Oracle Help Center: https://docs.oracle.com/cd/E28280_01/ core.1111/e10103/intro.htm

[8] Shilpi Taneja, A. G. (2015). A Mobile App Architecture for Student Information System. International Journal Web Applications, 56-63.

[9] techopedia. (2019). techopedia. Diambil kembali dari Middleware: https://www.techopedia.com/definition /450/middleware 